\title{
MORBIDITY DUE TO ARI IN PRESCHOOL CHILDREN IN RELATION TO COOKING FUEL, OCCUPATION AND FAMILY SIZE.
}

\author{
Anju Gahlot, Amit Jha, Sanjay Kumar Nigam, Nilam Nigam
}
1. Associate Professor, Department of Community Medicine, Rama Medical College Hospital \& Research Centre, Mandhana, Kanpur, Uttar Pradesh.
2. Assistant Professor, Department of Community Medicine, Rama Medical College Hospital \& Research Centre, Mandhana, Kanpur, Uttar Pradesh.
3. Professor, Department of Pathology, Rama Medical College Hospital \& Research Centre, Mandhana, Kanpur, Uttar Pradesh.
4. Associate Professor, Department of Pharmacology, Rama Medical College Hospital \& Research Centre, Mandhana, Kanpur, Uttar Pradesh.

\section{CORRESPONDING AUTHOR}

Dr. Sanjay Kumar Nigam

House No. 308,

Rama Medical College,

Mandhana, Kanpur, Uttar Pradesh.

E-mail: sknigam@yahoo.com

Ph: 00919411918206.

ABSTRACT: INTRODUCTION: Indoor air pollution \& occupation family size, have been known to play an important role in prevalence of ARI especially in developing countries like India. These factors alone contribute to $20-30 \%$ incidence of pneumonia in developing countries as opposed to 3-4\% incidence in developed countries. MATERIAL \& METHODS: A prospective one year longitudinal study was conducted among 3135 children of pre-school age group belonging to rural field practice area of 'Rama Medical College \& research center'. They constituted $14.94 \%$ of the total population. RESULTS \& DISCUSSION: All children under 5 years of ages were examined for sign and symptoms and severity of ARI and no of average episodes. For every 5 children studied, 4 suffered from ARI. Children from families where wood was used as cooking fuel suffered 3.33 average episodes in contrast to children from families where gas was used suffered 2.40 average episodes. Respiratory episodes were highest 4.19 average episode in families with maximum family members. Although bacteria and viruses are the immediate causes of most acute respiratory infections, malnutrition, air pollution, smoking, and overcrowding are the underlying drivers of vulnerability. CONCLUSION: It was therefore concluded that type of fuel \& occupation and family size played a key role in determining severity of ARI. A reduction in these risk factors can strategically lower the prevalence of ARI among rural community.

KEYWORDS: Acute respiratory tract infection, preschool children, morbidity.

INTRODUCTION: Acute respiratory infections (ARI) are also important causes of morbidity and mortality in children worldwide. An estimated 4.3 million deaths every year are attributed to ARI. About 33\% of these deaths occur in the under five population. According to the world health organization (WHO) children below 5 years of age in the developing world suffer about 2-6 episodes of ARI annually. [1,9]

Despite their toll, acute respiratory infection has been called "the forgotten pandemic" because they have not attracted sufficient attention from governments, the global health community. [2] 
Every year some 12 million children in developing countries die before they reach their fifth birthday, many during the first year of life. Seven in ten of these deaths are due to acute respiratory infections (mostly pneumonia), diarrhea, measles, malaria or malnutrition or a combination of these conditions. [3]

ARIs are the leading cause of illness and death in children worldwide according to the atlas malnutrition in utro, during infancy and in early childhood is a major culprit. The impaired development of a fully functioning immune system makes young children particularly susceptible to ARIs. [4]

ARI accounts for $20 \%$ of all deaths among children of the age group 0-14 years and highest mortality has been reported among infants where the death rate in some countries even exceeds 2000 per 1,00,000 live births. [5]

Acute respiratory infection (ARI) is an acute infection of any part of the respiratory tract and related structures including paranasal sinuses, middle ear and pleural cavity. [6]

The development and implementation of a control programme for ARI is an essential component of primary health care approach. [7]

\section{MATERIAL \& METHODS:}

\section{(1) Type of Study:}

Descriptive, epidemiological community based study done by interview method of the mothers, of the children aged 0-5 years in the PHC, sub centre, remote villages of RHTC Shivrajpur.

\section{(2) Study Area:}

(a) 26 villages of Shivrajpur RHTC service area under Community Medicine Department of RMC, Kanpur. 26 villages were selected to give complete coverage of rural population. Villages were divided into strata-PHC village, sub-centre, village remote, and village. Villages \& household from each stratum were selected by simple random technique \& total 3135 , under 5 population were registered for study.

\section{(3) Methodology:}

The longitudinal study was conducted in field practice areas of rural field training centre (RFTC), Shivrajpur managed by Community Medicine Department of Rama Medical College Hospital \& Research Centre, Mandhana, Kanpur from Jan. 2009 to Dec. 2009. This RHTC provides health service to surrounding 62 villages. Out of these 26 villages were selected, to give complete coverage of rural population. The children were 3135 in number \& constituted about $14.94 \%$ of total population. Workers were trained to diagnose \& manage ARI on WHO guidelines.

House to house visit was conducted to collect necessary information. After explaining the aim of study an interview was conducted by questionnaire method. Information collected was entered in Performa \& fortnightly follow ups were done. Reports were collected at monthly interval. $10 \%$ of the work was checked by direct observation. Reports collected at monthly interval were analyzed in Dept. of Community Medicine by direct observation.

Assessment of knowledge \& skill of workers to recognize \& manage ARI were done using WHO guidelines. Training package included. 
1) Identification of ARI.

2) Management of ARI.

3) Referral.

4) Impart Health Education to mothers.

Health education was given to mothers in groups of 20-25 with help of flip charts, photographs, posters.

(4) Inclusion Criteria: Any child having one or more of following symptoms was identified as ARI case.

- Cough.

- Blocked/Running nose.

- Ear ache/ discharge.

- Sore throat.

- Difficulty in breathing/ nosily breathing.

- Fever present or absent.

-

New episode was considered as in which patient. Had been free of symptoms for last 48 hrs.

\section{(5) Exclusion criteria:}

1. Patients having history of cough greater than 7 days were excluded from the study.

2. Children whose families had not been residing in the community for the past 3 months.

3.

(6) Statistical analysis:

Data were pooled and evaluated.

Data analysis was done by-

1. Calculating the percentages.

2. Applying the Chi-square test.

RESULT \& DISCUSSION: In the present study total 3135 under five study subjects were enrolled. Sex wise distribution of males was $54.67 \%$ and females were $45.33 \%$ respectively. Out of 3135 study subjects, age wise distribute was $24.30 \%$ in $0-1$ years, $22.99 \%$ were $1-2$ years age group, $19.20 \%$ were $2-3$ years age group, $16.81 \%$ were in $3-4$ years age group $<5$ were $16.68 \%$.

$20.98 \%$ of population didn't suffer from any episodes of ARI, $79.02 \%$ of population suffered from one or more episodes of ARI (10122) table 1. This was Due to the fact that respiratory infections spread by the aerosol route and hence very difficult to prevent. Out of the total episodes (10122) maximum 87.69\% (8873) episodes were mild, 9.18\% (938) were moderate, and $3.13 \%$ (320) were of severe grade. Thus giving an average episode of $3.23 \% /$ child/year.

Children from family where, family members $<4$ suffered total minimum episodes (19.92\%) total 2017 episode, and an average episode of 2.65. Children from family with family member 5-8, 9-12, +12 suffered from average episode of 3, 3.5, and 4.19 respectively. Highest average episode was in family with more than 12 members. (Table no. 2) Which may be due to the fact of relatively lowered attention paid by the mother with increased family size. The 
lowest average episode was in 1-4 and this difference was found statistically highly significant $\mathrm{P}<.001$.

Children from families where wood was mainly used as fuel suffered highest average episode 3.34 (table no. 3) this could be correlated with the fact that during wood burning polyaromatic hydrocarbons are released which act as strong irritant to the respiratory mucosa membrane. In our present study maximum children 2641 (84.24) were from families where wood was mainly used. This could be explained by the fact that wood is easily available in villages and food cooked in chullah is believed to be more palatable. The comparative less consumption of kerosene and gas was due to the fact of lack of easy availability of these items. In the present study of under five population maximum episodes $41.67 \%$ (4218), 38.54 (3902) episodes were suffered by the children of farmers and labourers respectively. This is attributed to the fact of their direct exposure to difference of temperature in the field. [8, 9]

CONCLUSION: Morbidity pattern of ARI is directly related to risk factors like family size, occupation, type of fuel. Thus the present study signifies of intensive health education campaigns to educate villagers on combating malnutrition, smokeless chullah and home remedies of ARI. Further the development and implementation of a control programme for ARI is strongly recommended in primary health care approach.

\section{REFERENCES:}

1. Dr. S.K Jain, Dr, J.A Khan- epidemiological study of acute diarrheal disease and acute respiratory infection amongst under five children in Alwar district (Rajasthan), India. Indian journal for the practicing doctor. 2006; 1-12

2. The acute respiratory infection atlas; first edition; retrived fromhttp://www.ariatlas.org/overview?id=0002,

3. Neeru Gupta, S.K Jain, Ratnesh, Uma Chawla, shah hosssain and S. venkatesh- An evaluation of diarrheal diseases and acute respiratory infection control programmes in a Delhi slum. Indian journal of pediatrics, 74; 49-54

4. New atlas details pendemic; Retrieve fromhttp://www.worldlungfoundation.org/ht/redisplay/1/printerfriendly/1

5. J. Mukhopadhya- A prospective study of factors affecting incidence of acute respiratory infection [ARI] among children of a service community. Health and population.1992;1825

6. Nilanjan kumar mitra- A longitudinal studies on ARI among rural under fives. Indian journal of community medicine 2010; 1-7

7. N. Datta, V. Kumar, L. Kumar and S. Singhi- application of case management to the control of acute respiratory infections in low birth weight infants: a feasibility study, 1987; bull world health organization 65; 77-82.

8. Deb SK Acute respiratory disease survey in Tripura in case of children below five years of age. J Indian Med assoc 1998 Apr ;96 (4) 111-6

9. Mehendra Dutta and R.S Sharma- prospects of national ARI control programme in India. Indian journal pediatrics 1987; 149-152 
Table No. 1 - ILLUSTRATES DISTRIBUTION OF ACUTE RESPIRACTORY INFECTION ACCORDING TO SEVERITY

\begin{tabular}{|c|c|c|}
\hline SR. NO. & GRADES OF A.R. INFECTION & TOTAL \\
\hline 1. & Mild & 8873 \\
& & $(87.69)$ \\
2. & Moderate & 938 \\
& & $(9.18)$ \\
3. & Severe & 320 \\
& & $(3.13)$ \\
\hline & Total episode & 10122 \\
\hline
\end{tabular}

Above table depicts that maximum $87.69 \%$ episode were of mild grade, only $9.18 \%$ were of moderate grade and $3.13 \%$ were of severe grade.

Table No. 2 - CO-RELATION BETWEEN FAMILY SIZE, SEVERITY OF A.R.I. AND AVERAGE EPISODE

\begin{tabular}{|c|c|c|c|c|}
\hline SR. NO. & $\begin{array}{c}\text { TOTAL FAMILY } \\
\text { MEMBERS }\end{array}$ & POPULATION & TOTAL & AVERAGE EPISODE \\
\hline 1. & $1-4$ & $\begin{array}{c}762 \\
(24.23)\end{array}$ & $\begin{array}{c}2017 \\
(19.92)\end{array}$ & 2.64 \\
\hline 2. & $5-8$ & $\begin{array}{c}1103 \\
(35.03)\end{array}$ & $\begin{array}{c}3320 \\
(32.79)\end{array}$ & 3.00 \\
\hline 3. & $9-12$ & $\begin{array}{c}774 \\
(24.80)\end{array}$ & $\begin{array}{c}2706 \\
(26.73)\end{array}$ & 3.50 \\
\hline \multirow[t]{2}{*}{4.} & +12 & $\begin{array}{c}496 \\
(15.93)\end{array}$ & $\begin{array}{c}2079 \\
(20.53)\end{array}$ & 4.19 \\
\hline & Total & $\begin{array}{c}3135 \\
(99.99)\end{array}$ & $\begin{array}{c}10122 \\
(100.0)\end{array}$ & \\
\hline & $X 2=37.89$ & $\mathrm{p}<.001$ & ly signific & \\
\hline
\end{tabular}

Average table depicts average respiratory episode was highest in family where member were more than 12 and lowest where family members were 1-4 and this different was found statistically significant. 
Table No. 3 - DEPICTS CORRELATION BETWEEN TYPE OF FUEL USED AND SEVERITY OF ARI AND AVERAGE EPISODE

\begin{tabular}{|c|c|c|c|c|}
\hline SR. NO. & FUEL USED & $\begin{array}{c}\text { TOTAL } \\
\text { POPULATION }\end{array}$ & TOTAL & AVERAGE EPISODE \\
\hline 1. & Wood & $\begin{array}{c}2641 \\
(84.26\end{array}$ & $\begin{array}{c}8808 \\
(87.06\end{array}$ & 3.34 \\
& & 408 & 1092 & 2.68 \\
2. & Coal & $(13.01)$ & $(10.76$ & \\
& & 81 & 210 & 2.59 \\
3. & Kerosene & $(2.58)$ & $(2.07)$ & \\
& & 5 & 12 & 2.40 \\
4. & Gas & $(0.15)$ & $(0.11)$ & \\
\hline & Total & 3135 & 10122 & \\
\hline & & $(100) 99.98$ & $(100.0)$ & \\
\hline
\end{tabular}

Children from families where wood was used suffered highest average 3.33, in contrast to children from families where gas was used suffered comparatively lesser episode of respiratory infection 2.40 .

Table No. 4 - CORRELATION BETWEEN OCCUPATION AND SEVERITY OF ARI AND AVERAGE EPISODE

\begin{tabular}{|c|c|c|c|c|}
\hline SR. NO. & OCCUPATION & POPULATION & TOTAL & AVERAGE EPISODE \\
\hline 1. & Farmer & $\begin{array}{c}1355 \\
(43.24)\end{array}$ & $\begin{array}{c}4218 \\
(41.67)\end{array}$ & 3.11 \\
\hline 2. & Labourer & $\begin{array}{c}1164 \\
(37.13)\end{array}$ & $\begin{array}{c}3902 \\
(38.54)\end{array}$ & 3.35 \\
\hline 3. & Businessman & $\begin{array}{c}184 \\
(5.86)\end{array}$ & $\begin{array}{c}610 \\
(6.02)\end{array}$ & 3.32 \\
\hline 4. & Teachers & $\begin{array}{c}86 \\
(2.74)\end{array}$ & $\begin{array}{c}288 \\
(2.84)\end{array}$ & 3.35 \\
\hline 5. & Govt. Servant & $\begin{array}{c}108 \\
(3.44)\end{array}$ & $\begin{array}{c}334 \\
(3.29)\end{array}$ & 3.09 \\
\hline 6. & Others & $\begin{array}{c}238 \\
(7.59)\end{array}$ & $\begin{array}{c}770 \\
(7.60)\end{array}$ & 3.24 \\
\hline & Total & 3135 & 10122 & \\
\hline
\end{tabular}


Average respiratory episode suffered by labours were 3.35, businessman were 3.31, teachers were 3.34 Farmers suffered from 3.11 respiratory episode and Govt. servants suffered from 3.09 respiratory episode.

Figure - 1 (table - 1.) PIE DIAGRAM SHOWING DISTRIBUTION OF GRADE OF ARI ACCORDING TO SEVERITY.

\section{ACUTE RESPIRATORY INFECTION GRADE.}

$\because$ MILD GRADE

MODERATE GRADE

而 SEVERE GRADE

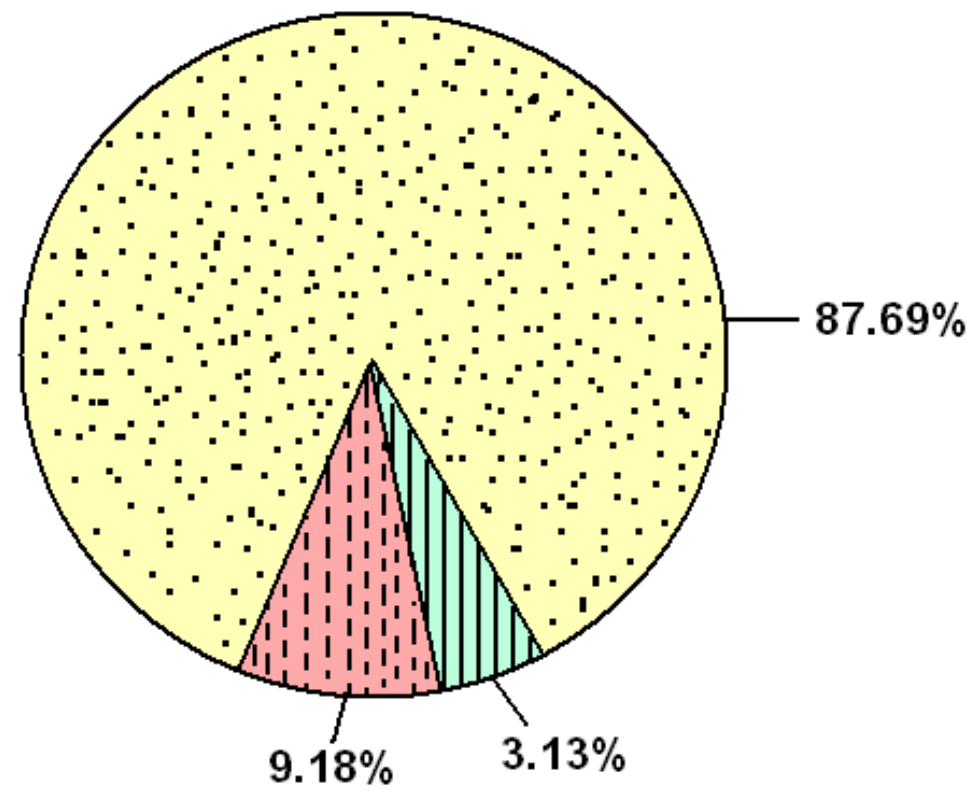

